\title{
Behavior of Pu and Gd Mixtures Under Simulated SRAT Conditions (U)
}

\author{
N. E. Bibler \\ M. G. Bronikowski \\ J. H. Gray \\ B. C. Hill
}

Westinghouse Savannah River Company

Savannah River Technology Center

Aiken, South Carolina 
This document was prepared in conjunction with work accomplished under Contract No. DE-AC09-96SR18500 with the U. S. Department of Energy.

\section{DISCLAIMER}

This report was prepared as an account of work sponsored by an agency of the United States Government. Neither the United States Government nor any agency thereof, nor any of their employees, makes any warranty, express or implied, or assumes any legal liability or responsibility for the accuracy, completeness, or usefulness of any information, apparatus, product or process disclosed, or represents that its use would not infringe privately owned rights. Reference herein to any specific commercial product, process or service by trade name, trademark, manufacturer, or otherwise does not necessarily constitute or imply its endorsement, recommendation, or favoring by the United States Government or any agency thereof. The views and opinions of authors expressed herein do not necessarily state or reflect those of the United States Government or any agency thereof.

This report has been reproduced directly from the best available copy.

Available for sale to the public, in paper, from: U.S. Department of Commerce, National Technical Information Service, 5285 Port Royal Road, Springfield, VA 22161, phone: (800) 553-6847, fax: (703) 605-6900

email: orders@ntis.fedworld.gov

online ordering: http://www.ntis.gov/help/index.asp

Available electronically at http://www.osti.gov/bridge

Available for a processing fee to U.S. Department of Energy and its contractors, in paper, from: U.S. Department of Energy, Office of Scientific and Technical Information, P.O. Box 62, Oak Ridge, TN 37831-0062,

phone: (865)576-8401,

fax: (865)576-5728

email: $\underline{\text { reports@ adonis.osti.gov }}$ 


\title{
Behavior of Pu and Gd Mixtures Under Simulated SRAT Conditions (U)
}

\author{
N. E. Bibler \\ M. G. Bronikowski \\ J. H. Gray \\ B. C. Hill
}

Westinghouse Savannah River Company

Savannah River Technology Center

Aiken, South Carolina

This report was prepared by Westinghouse Savannah River Company (WSRC) for the United States Department of Energy under Contract No. DE-AC09-96SR18500 and is an account of work performed under that contract. 


\begin{tabular}{|c|c|c|c|}
\hline $\begin{array}{l}\text { Task Title: } \\
\text { Evaluation of Am/Cm on } \mathrm{H}_{2} \\
\text { Generation and Glass Quality }\end{array}$ & $\begin{array}{l}\text { ITS Task Number: } \\
\text { NA }\end{array}$ & $\begin{array}{l}\text { TTR Number: } \\
\text { NMMD-HTS-2002- } \\
010,1 / 24 / 2002\end{array}$ & \begin{tabular}{|l} 
TAR/TTR Date \\
$3 / 6 / 2002$
\end{tabular} \\
\hline $\begin{array}{l}\text { Author: } \\
\text { N.E. Bibler }\end{array}$ & Signature: & $\begin{array}{l}\text { Organization: } \\
\text { ITS }\end{array}$ & Date: \\
\hline $\begin{array}{l}\text { Author: } \\
\text { M. G. Bronikowski }\end{array}$ & \begin{tabular}{|l} 
Signature: \\
\end{tabular} & $\begin{array}{l}\text { Organization: } \\
\text { ATS }\end{array}$ & Date: \\
\hline $\begin{array}{l}\text { Co-author: } \\
\text { J. H. Gray }\end{array}$ & Signature: & $\begin{array}{l}\text { Organization: } \\
\text { ATS } \\
\end{array}$ & Date: \\
\hline $\begin{array}{l}\text { Co-author: } \\
\text { B. C. Hill } \\
\end{array}$ & Signature: & $\begin{array}{l}\text { Organization: } \\
\text { ATS }\end{array}$ & Date: \\
\hline $\begin{array}{l}\text { Technical Reviewer: } \\
\text { T. L. Fellinger }\end{array}$ & Signature: & $\begin{array}{l}\text { Organization: } \\
\text { ITS }\end{array}$ & Date: \\
\hline $\begin{array}{l}\text { Technical Reviewer: } \\
\text { M. E. Summers }\end{array}$ & Signature: & $\begin{array}{l}\text { Organization: } \\
\text { ADS }\end{array}$ & Date: \\
\hline $\begin{array}{l}\text { Technical Reviewer: } \\
\text { H.H. Elder }\end{array}$ & Signature: & $\begin{array}{l}\text { Organization: } \\
\text { HLW-PE }\end{array}$ & Date: \\
\hline $\begin{array}{l}\text { Technical Reviewer: } \\
\text { F. R. Graham }\end{array}$ & \begin{tabular}{|l} 
Signature: \\
\end{tabular} & $\begin{array}{l}\text { Organization: } \\
\text { ATS }\end{array}$ & Date: \\
\hline $\begin{array}{l}\text { Level } 4 \text { Manager: } \\
\text { S.L. Marra }\end{array}$ & Signature: & $\begin{array}{l}\text { Organization: } \\
\text { ITS }\end{array}$ & Date: \\
\hline $\begin{array}{l}\text { Level } 4 \text { Manager: } \\
\text { R.H. Spires }\end{array}$ & Signature: & $\begin{array}{l}\text { Organization: } \\
\text { ITS }\end{array}$ & Date: \\
\hline $\begin{array}{l}\text { Level } 4 \text { Manager: } \\
\text { A. M. Murray }\end{array}$ & Signature: & $\begin{array}{l}\text { Organization: } \\
\text { ATS }\end{array}$ & Date: \\
\hline
\end{tabular}


Immobilization Technology Section

WSRC-TR-2002-00211

Savannah River Technology Center

Rev. 0

Westinghouse Savannah River Company

Page 5 of 26

\section{Table of Contents:}

$\begin{array}{ll}\text { Introduction and Summary } & \text { p. } 7\end{array}$

$\begin{array}{ll}\text { Experimental p. } 9 & \text { p. }\end{array}$

Results and Discussion $\quad$ p. 11

Observations during Heating and Final pH Values $\quad$ p. 11

Measured Concentrations in the Supernates after the Tests $\quad$ p. 11

Appearance of the Solids in Settled and Centrifuged Slurries $\quad$ p. 12

$\begin{array}{ll}\text { SEM Examination of the Centrifuged Solids } & \text { p. } 15\end{array}$

$\begin{array}{ll}\text { Conclusion } & \text { p. } 24\end{array}$

$\begin{array}{ll}\text { References } & \text { p. } 25\end{array}$ 
Immobilization Technology Section

WSRC-TR-2002-00211

Savannah River Technology Center

Rev. 0

Westinghouse Savannah River Company

Page 6 of 26

\section{List of Tables:}

Table 1. Compositions of Mixtures used for the Simulated SRAT Tests

Table 2. Targeted, Initial, and Final pH Values of the Simulated SRAT Tests

p. 12

Table 3. Concentrations (Molarity) of Elements in the Final Supernates of the Simulated SRAT Tests

p. 13

Table 4. Fractions (Percent) of Pu, Gd, and Major Sludge Elements Soluble in the Final Supernates of the Simulated SRAT Tests

\section{List of Figures:}

Figure 1. Sludge appearance while SRAT cycle was being run.

Figure 2. Centrifuged $\mathrm{Pu} / \mathrm{Gd}$ and sludge solids after the simulated SRAT heating cycle....

Figure 3. Centrifuged sludge solids; A) final simulated SRAT cycle product (Fellinger 2002), B) washed sludge sample with Pu Gd solids,

C) de-washed simulated sludge prior to washing or Pu addition,

D) washed sludge sample with $\mathrm{Pu} / \mathrm{Gd}$ solids....

Figure 4. Sludge appearance after settling one month from the completion of the simulated SRAT run....

Figure 5. EDS Spectrum of particles from the Supernate Test (final $\mathrm{pH}=3.5$ ).

p. 20

Figure 6. Scanning Electron Micrograph of sludge and Pu particles in centrifuged solids of Test Sludge-5 (final $\mathrm{pH}=6.0 \pm 0.5$ ).

Figure 7. Scanning Electron Micrograph of sludge and Pu particles in centrifuged solids of Test Sludge-5 (final $\mathrm{pH}=6.0 \pm 0.5$ ) at a higher magnification. Particles that were analyzed by EDS are designated by the arrows.

Figure 8. EDS spectrum of the sludge particles (Primarily Fe and Al) in centrifuged solids of Test Sludge-5 (final $\mathrm{pH}=6.0 \pm 0.5$ ).

Figure 9. EDS spectrum of the $\mathrm{Zr}$ containing particles in centrifuged solids of Test Sludge-5 (final $\mathrm{pH}=6.0 \pm 0.5$ ).

Figure 10. EDS spectrum of Pu particles found in the centrifuged solids of Sludge-5 Test (final $\mathrm{pH}=6.0 \pm 0 / 5$ ). 


\section{Introduction and Summary}

The Defense Waste Processing Facility (DWPF) will begin to process Sludge Batch 3 (SB3) in spring of 2004. It has been proposed that $100 \mathrm{~kg}$ of excess plutonium (Pu) from the H-Canyon be added to SB3 for disposal in the high level waste (HLW) glass produced by the DWPF. The excess Pu will be coprecipitated in H-Canyon with gadolinium $(\mathrm{Gd})$ as a neutron absorbent to ensure criticality safety. The precipitated material will be transferred to Tank 51 and mixed into SB3 prior to processing in the DWPF. The Nuclear Materials Management Division (NMMD) issued a Task Technical Request (TTR-NMMD-HTS-2002-010) requesting the Savannah River Technology Center (SRTC) to address possible impacts on the Tank Farm and DWPF by this addition. Two reports have already been issued that assess the impacts at the expected $\mathrm{Pu} / \mathrm{Gd}$ concentrations in SB3 (Fellinger,2002, and Peeler, 2002). No deleterious impacts on Tank Farm and DWPF processing were discovered in those studies. However, neither of those studies could address whether or not the Pu and Gd stayed together as a coprecipitated matrix under the slightly acidic conditions in the DWPF Slurry Receipt Adjustment Tank (SRAT).

This report presents results of a study designed to investigate the possibility of the separation of the Pu and Gd during processing in the SRAT. In the SRAT, nitric and formic acids are added to the caustic sludge to adjust its rheology and reduce the mercury $(\mathrm{Hg})$ to the metallic state in the sludge so it can be steam stripped from the sludge prior to sending the sludge to the DWPF melter. Experimentally, the $\mathrm{Pu} / \mathrm{Gd}$ precipitate was treated in the absence and the presence of a simulated HLW sludge using probable SRAT conditions (acid addition, mixing, and heating for eleven hours at $\mathrm{pH}$ values in the range of 3-6). The resulting solids were then examined by Scanning Electron Microscopy (SEM) to see if the Pu and Gd had separated. The supernate was also analyzed to determine the fraction of $\mathrm{Pu}$ and $\mathrm{Gd}$ that remained in the solids.

In order to detect the $\mathrm{Pu} / \mathrm{Gd}$ precipitate, the initial $\mathrm{Gd} / \mathrm{Pu}$ concentration in the sludge was increased to nominally $25 \mathrm{X}$ higher than the amount usually contained in the sludge. The 
expected $\mathrm{Pu}$ concentration in SB3 is $\sim 0.04$ weight percent on a calcined oxide basis (Peeler, 2002). In this study that concentration was increased to approximately $1 \mathrm{wt} . \%-$ a concentration that probably will never be present in the HLW tanks at SRS. It was expected that at this higher concentration in the sludge, the $\mathrm{Pu} / \mathrm{Gd}$ solids could be detected by SEM. Five tests were performed with the $\mathrm{Pu} / \mathrm{Gd}$ precipitate in the presence of simulated sludge and one test in the absence of sludge. Results are summarized below:

1. In the single test in the absence of sludge, the $\mathrm{Pu} / \mathrm{Gd}$ precipitate was treated with simulated SRAT supernate at $\mathrm{pH}$ 3.5. In this extreme test, the Gd had completely dissolved while $90 \%$ of the Pu remained insoluble. SEM examination of the solids indicated the presence of $\mathrm{Pu}$ in the solids and no $\mathrm{Gd}$. Thus, separation is possible at this low $\mathrm{pH}$.

2. In four of the five tests in presence of sludge, the Pu and Gd were undetectable in centrifuged solids by SEM. The Pu and Gd particle sizes were either too small or they had been dispersed throughout the sludge so that their concentrations were too low to be detected by SEM. The $\mathrm{pH}$ of these tests ranged from 3.5 to 4.5 . Thus it could not be determined if any separation had occurred. In these tests, 22 to $47 \%$ of the Gd had dissolved while only 0.7 to $6.4 \%$ of the $\mathrm{Pu}$ dissolved, or 93.6 to $99.3 \%$ of the $\mathrm{Pu}$ remained insoluble.

3. In a single sample of the centrifuged solids from the test in the presence of sludge at pH 6 several Pu particles were detected by SEM. These particles contained no Gd, were very small (<20 microns), and were surrounded by sludge particles. In this test, $99.7 \%$ of the $\mathrm{Pu}$ and $87 \%$ of the Gd were still precipitated in the solids.

4. Other components in the sludge such as iron $(\mathrm{Fe})$, calcium $(\mathrm{Ca})$, aluminum $(\mathrm{Al})$, nickel (Ni), magnesium (Mg), and manganese (Mn) had measurable solubilities in the supernate after the SRAT process similar to those observed when simulated SB3 was tested with the expected concentration of Pu and Gd (Fellinger, 2002).

Even though a few particles were detected that indicated that the $\mathrm{Pu}$ and $\mathrm{Gd}$ could separate during the SRAT process, it is impossible to conclude that all the $\mathrm{Pu} / \mathrm{Gd}$ in the solids separate. This is because nearly all of the $\mathrm{Pu} / \mathrm{Gd}$ in the solids were not detected by the SEM analysis. The Pu/Gd particles may be below the limit of detection of this 
method due to their small size and the large amount of sludge present. What can be reported is that a few small $(<20$ micron) Pu particles that no longer contain detectable Gd were observed by SEM in one of the tests.

\section{Experimental}

The question whether the $\mathrm{Gd}$ in the $\mathrm{Pu} / \mathrm{Gd}$ precipitate remained with the Pu during waste processing in the SRAT was to be answered by running an experiment that would bound the process. Various $\mathrm{pH}$ values under simulated SRAT conditions were run on a simulated sludge. SEM was used to detect the Pu and Gd spatial distribution in the solids,. The sludge would need to be spiked with at least $1 \mathrm{wt} \% \mathrm{Pu}$ in order to detect the Pu by this method with all of the Fe and other sludge components present.

Six tests were performed using the $\mathrm{Pu} / \mathrm{Gd}$ solids that were prepared by caustic precipitation of 18.3 solution from H-Canyon (Bronikowski, 2002). The precipitated solids had a mass ratio for the $\mathrm{Gd}$ to $\mathrm{Pu}$ of 1.4 to 1.0. Sufficient $\mathrm{Pu} / \mathrm{Gd}$ solids as a caustic slurry were added to six centrifuge tubes so that $\sim 10 \mathrm{mg}$ of Pu were in each tube. Details of the composition of the final mixture in each tube are presented in Table 1. Each tube was then centrifuged and the caustic supernate decanted from the solids. The solids were then washed with inhibited water $\left(0.015 \mathrm{M} \mathrm{NaOH}\right.$ and $\left.0.015 \mathrm{M} \mathrm{NaNO}_{2}\right)$ to simulate the washing that will occur for SB3. The wash solutions were decanted from the solids after centrifugation. To five of the centrifuge tubes, washed simulated sludge slurry was added to the $6 \mathrm{ml}$ mark. To the final tube, the wash supernate from the simulated slurry second washing was added to examine the behavior of the $\mathrm{Pu} / \mathrm{Gd}$ mixture in the absence of sludge. The contents were weighed and mixed.

The simulated sludge and supernate used were the same as that used in the SRAT demonstration process (process (Fellinger, 2002). The simulated slurry was at the expected concentration of $\mathrm{Pu} / \mathrm{Gd}$ solids present $(0.04 \mathrm{wt} . \%)$ in the sludge. The slurry was $15.3 \mathrm{wt} . \%$ total solids and had a density of $1.14 \mathrm{~g} / \mathrm{mL}$, thus each of the five tubes 
contained nominally one gram of dried sludge, $10 \mathrm{mg}$ of $\mathrm{Pu}$, and $14 \mathrm{mg}$ of Gd. The weight fraction of the $\mathrm{Pu}$ in the dried solids was then $1 \%$. This is $\sim 25 \mathrm{X}$ higher than that expected in SB3 on a dried sludge basis.

Calculated amounts of 50wt.\% nitric and 88 wt. $\%$ formic acid (see Table 1) were added to each tube with simulate slurry in it to adjust the final $\mathrm{pH}$ values of the respective mixtures to $3,4,5,7$, and 11 . The $\mathrm{pH}$ of the $\mathrm{Pu} / \mathrm{Gd}$ slurry with sludge supernate was to be adjusted to 5 . The $\mathrm{HNO}_{3}$ was added by weight along with enough deionized (DI) water to bring the acid water mix to $1 \mathrm{~g}$. This method allowed an easy addition of all of the nitric acid. The $\mathrm{pH}$ was measured and is listed as Sludge $\mathrm{pH}$ with $\mathrm{HNO}_{3}$ in Table 1. The centrifuge tubes were then moved to the glovebox. The formic acid was mixed into the sludge by three times adding sludge to the weighed formic acid and returning the sludge to the tube. Finally, the spiked sludge with the formic acid in each centrifuge tube was emptied into the reaction vials.

As shown in Table 1 as the Initial SRAT adjusted $\mathrm{pH}$, the correct target $\mathrm{pH}$ values were not attained after formic acid addition. This deviation was primarily due to the buffering capacity of the formic acid in the $\mathrm{pH}$ range of 3 to 4 . From Table 1, the measured $\mathrm{pH}$ values at the start of the test ranged from $3.5 \pm 0.5$ to $4.0 \pm 0.5$. (Due to the small openings in the centrifuge tubes, the $\mathrm{pH}$ had to be measured with $\mathrm{pH}$ paper that had an uncertainty of $\pm 0.5 \mathrm{pH}$ units to the measurement.) A small magnetic stirrer was then placed in each reaction vial and each vial placed in the water bath. The slurries were continuously mixed by the stir bar and heating was initiated. The temperature was raised to $93^{\circ} \mathrm{C}$ in two hours and heated for 10 hours at $93^{\circ} \mathrm{C}$ to simulate a DWPF SRAT cycle. Each tube had a specially designed condenser on it so that water loss during the 10 hours of heating was minimal. 
Table 1. Compositions of Mixtures used for the Simulated SRAT Tests (a)

\begin{tabular}{|c|c|c|c|c|c|c|c|c|}
\hline $\begin{array}{c}\text { Pu/Gd } \\
\text { Test }\end{array}$ & $\begin{array}{c}\text { Target } \\
\mathbf{p H}\end{array}$ & $\begin{array}{c}\text { Milligrams } \\
\text { Pu }\end{array}$ & $\begin{array}{c}\text { Milligrams } \\
\text { Gd }\end{array}$ & $\begin{array}{c}\text { Grams } \\
\text { Sludge } \\
\text { Slurry }\end{array}$ & $\begin{array}{c}\text { Grams } \\
\mathbf{5 0 \%} \\
\mathbf{H N O}_{\mathbf{3}}\end{array}$ & $\begin{array}{c}\text { Grams } \\
\mathbf{8 0 \%} \\
\text { Formic }\end{array}$ & $\begin{array}{c}\text { Sludge } \\
\mathbf{p H} \\
\text { with } \\
\text { HNO }\end{array}$ & $\begin{array}{c}\text { Initial } \\
\text { SRAT } \\
\text { adjusted } \\
\text { pH }\end{array}$ \\
\hline Supernate & 5 & 10.06 & 14.08 & 0.00 & 0.24 & 0.40 & 5.5 & 3.5 \\
\hline Sludge-1 & 3 & 9.68 & 13.56 & 5.95 & 0.27 & 0.46 & 5.0 & 3.5 \\
\hline Sludge-2 & 4 & 10.55 & 14.77 & 6.27 & 0.26 & 0.44 & 5.0 & 3.5 \\
\hline Sludge-3 & 5 & 10.43 & 14.60 & 5.66 & 0.22 & 0.37 & 6.5 & 3.5 \\
\hline Sludge-4 & 7 & 9.03 & 12.65 & 5.97 & 0.20 & 0.34 & $6.5-7.0$ & 3.5 \\
\hline Sludge-5 & 11 & 10.97 & 15.35 & 6.05 & 0.17 & 0.30 & $\begin{array}{l}>10, \\
<12.6\end{array}$ & 4.0 \\
\hline
\end{tabular}

(a) Final Volume in each tube was nominally $7 \mathrm{~mL}$.

After the heating period and the slurries had cooled, $4 \mathrm{ml}$ aliquots of slurry were removed. The slurries were centrifuged to concentrate the solids and allow a sample of the supernate to be taken. The $\mathrm{pH}$ of the supernate was measured. The supernate was analyzed by Inductively Couple Plasma Emission Spectroscopy (ICP-ES) to determine the concentration of $\mathrm{Gd}$ and other elements and by alpha counting to determine the $\mathrm{Pu}$ concentration. Samples of the solids were analyzed by SEM and an Energy Dispersive Spectrometer (EDS). This method detects characteristic x-rays of the major elements (excluding oxygen and or the lighter elements) in the particular particle that is being observed in the electron microscope.

\section{Results and Discussion}

\section{Observations during Heating and Final pH Values}

At temperatures above $40^{\circ} \mathrm{C}$ small bubbles appeared in all the mixtures and then later ceased. These were probably $\mathrm{CO}_{2}$ being released from the caustic solutions at the low $\mathrm{pH}$ values. Brown gas evolved for a while from the mixtures containing sludge but not from the mixture containing only the $\mathrm{Pu} / \mathrm{Gd}$ and slurry supernate. This gas was probably $\mathrm{NO}_{2}$ from decomposition of nitrites in the sludge slurry. The soluble nitrite in the supernate was also decomposed so the brown gas should have been evolved from the mixture of just the $\mathrm{Pu} / \mathrm{Gd}$ and slurry supernate. The reason for it not forming in this mixture is not 
obvious unless the concentration of nitrite is higher in the sludge slurry than the supernate. Three hours into the heating the stir bars were not sufficient to keep the solids completely dispersed in the vials containing the sludge so the vials were swirled manually at various times. At the end of the heating period sludges appeared thicker and adhered more to the sides of the reaction vials.

The measured final $\mathrm{pH}$ values are compared to the targeted and initial values in Table 2 . Within the accuracy of the $\mathrm{pH}$ paper, the $\mathrm{pH}$ of the final supernates increased in those mixtures where the amount of added acids were less (i.e. mixtures 3, 4, and 5). In these mixtures, the acid contents were low enough so that reaction of the acid with bases in the mixtures could cause the $\mathrm{pH}$ to rise. Examples of such bases are hydroxides and carbonates.

Table 2. Targeted, Initial, and Final pH Values of the Simulated SRAT Tests

\begin{tabular}{|c|c|c|c|}
\hline $\begin{array}{c}\text { Pu/Gd } \\
\text { Test }\end{array}$ & $\begin{array}{c}\text { Target } \\
\mathbf{p H}\end{array}$ & $\begin{array}{c}\text { Initial } \\
\mathbf{p H}\end{array}$ & $\begin{array}{c}\text { Final } \\
\mathbf{p H}\end{array}$ \\
\hline Supernate & 5 & 3.5 & 3.5 \\
\hline Sludge-1 & 3 & 3.5 & 3.5 \\
\hline Sludge-2 & 4 & 3.5 & 3.5 \\
\hline Sludge-3 & 5 & 3.5 & 4.0 \\
\hline Sludge-4 & 7 & 3.5 & 4.5 \\
\hline Sludge-5 & 11 & 4.0 & 6.0 \\
\hline
\end{tabular}

Measured Concentrations in the Supernates after the Tests

After the 10 hour heating was complete, the slurries were allowed to cool overnight. The slurries were then remixed and a $4 \mathrm{~mL}$ aliquot of each slurry was transferred to a centrifuge tube. Each aliquot was then centrifuged and a sample of the clear supernate was decanted and submitted for ICP-ES analysis and alpha counting.

The molar concentrations of the $\mathrm{Pu}, \mathrm{Gd}$, and major sludge components in the supernates after the simulated SRAT runs are shown in Table 3. A supernate density of $1.07 \mathrm{~g} / 1$ was used in calculating the molar concentrations from the measured ppm concentrations as 
Immobilization Technology Section

WSRC-TR-2002-00211

Savannah River Technology Center

Rev. 0

Westinghouse Savannah River Company

Page 13 of 26

was done in the SRAT demonstration. The molar concentrations of Pu were calculated

from the $\mathrm{Pu}$ activity after correcting for ${ }^{241} \mathrm{Am}$. The last row in the Table 3 presents

Table 3. Concentrations (Molarity) of Elements in the Final Supernates of the Simulated SRAT Tests

\begin{tabular}{|c|c|c|c|c|c|c|c|c|c|}
\hline $\begin{array}{c}\text { Pu/Gd } \\
\text { Test }\end{array}$ & $\begin{array}{c}\text { Final } \\
\mathrm{pH}\end{array}$ & $\mathrm{Pu}$ & $\mathrm{Gd}$ & $\mathrm{Fe}$ & $\mathrm{Ca}$ & $\mathrm{Al}$ & $\mathrm{Ni}$ & $\mathrm{Mg}$ & $\mathrm{Mn}$ \\
\hline Supernate & 3.5 & $6.46 \mathrm{E}-07$ & $1.63 \mathrm{E}-02$ & $1.76 \mathrm{E}-03$ & - & - & - & - & - \\
\hline Sludge-1 & 3.5 & $4.26 \mathrm{E}-07$ & $9.73 \mathrm{E}-03$ & $8.01 \mathrm{E}-03$ & $1.13 \mathrm{E}-01$ & $1.02 \mathrm{E}-01$ & $6.96 \mathrm{E}-02$ & $1.24 \mathrm{E}-02$ & $1.08 \mathrm{E}-01$ \\
\hline Sludge-2 & 3.5 & $2.22 \mathrm{E}-07$ & $8.93 \mathrm{E}-03$ & $5.14 \mathrm{E}-03$ & $1.14 \mathrm{E}-01$ & $7.47 \mathrm{E}-02$ & $7.00 \mathrm{E}-02$ & $1.26 \mathrm{E}-02$ & $1.12 \mathrm{E}-01$ \\
\hline Sludge-3 & 4.0 & $7.75 \mathrm{E}-08$ & $8.45 \mathrm{E}-03$ & $3.43 \mathrm{E}-03$ & $1.06 \mathrm{E}-01$ & $4.96 \mathrm{E}-02$ & $6.32 \mathrm{E}-02$ & $1.17 \mathrm{E}-02$ & $1.02 \mathrm{E}-01$ \\
\hline Sludge-4 & 4.5 & $4.90 \mathrm{E}-08$ & $4.19 \mathrm{E}-03$ & $1.05 \mathrm{E}-03$ & $8.28 \mathrm{E}-02$ & $1.20 \mathrm{E}-02$ & $4.30 \mathrm{E}-02$ & $9.07 \mathrm{E}-03$ & $7.91 \mathrm{E}-02$ \\
\hline Sludge-5 & 6.0 & $2.12 \mathrm{E}-08$ & $2.91 \mathrm{E}-03$ & $6.71 \mathrm{E}-04$ & $1.00 \mathrm{E}-01$ & $3.21 \mathrm{E}-03$ & $3.86 \mathrm{E}-02$ & $1.11 \mathrm{E}-02$ & $9.08 \mathrm{E}-02$ \\
\hline SRAT (a) & 3.8 & $2.91 \mathrm{E}-07$ & $1.08 \mathrm{E}-04$ & $3.10 \mathrm{E}-03$ & $1.03 \mathrm{E}-01$ & $4.00 \mathrm{E}-02$ & $5.95 \mathrm{E}-02$ & $1.27 \mathrm{E}-02$ & $1.04 \mathrm{E}-01$ \\
\hline
\end{tabular}

(a) Results of SRAT cycle with expected $\mathrm{Pu} / \mathrm{Gd}$ concentrations (Fellinger, 2002).

the molar concentrations calculated from measured concentrations in the supernate of the SRAT demonstration performed with the expected concentration of $\mathrm{Pu}$ and $\mathrm{Gd}$ in SB3 (see Table 21 of Fellinger, 2002). In the supernate of the test in absence of sludge ( $\mathrm{Pu} / \mathrm{Gd}$ Test Supernate) Fe was detected because it was an impurity in the 18.3 solution that was precipitated (Bronikowski, 2002). In the tests with sludge present note that the concentrations of $\mathrm{Pu}, \mathrm{Gd}, \mathrm{Fe}$, and aluminum ( $\mathrm{Al}$ ) decrease as the $\mathrm{pH}$ increases as would be expected of slightly soluble hydroxides. For first three tests with sludge present, the concentrations of $\mathrm{Ca}, \mathrm{Mg}$, and $\mathrm{Mn}$, are constant within experimental error suggesting that possibly these elements were completely dissolved from the sludge in these three tests. Note also that these respective concentrations are equal to those in the test when the SRAT cycle was performed with the expected concentration of $\mathrm{Pu} / \mathrm{Gd}$ in the sludge. Results of that test indicated that at a $\mathrm{pH}$ of 3.8 essentially $100 \%$ of these three elements were soluble (see Table 24 of Fellinger, 2002). Thus they would also be completely soluble at the lower $\mathrm{pH}$ values in the simulated SRAT tests.

Test Sludge-3 had a final $\mathrm{pH}$ value closest to 3.8 (the $\mathrm{pH}$ value for the SRAT test with the expected $\mathrm{Pu} / \mathrm{Gd}$ concentration). In this test, Sludge-3, the concentrations of the Fe and other sludge components were essentially equal to those in the SRAT test with the expected $\mathrm{Pu} / \mathrm{Gd}$ concentration. However this was clearly not the case for $\mathrm{Pu}$ and $\mathrm{Gd}$ 
where the concentrations of soluble Pu and Gd in the two tests differed by approximately 0.27 and 78X, respectively. More Gd was dissolved in the simulated SRAT tests where the concentration of $\mathrm{Pu}$ and $\mathrm{Gd}$ were $\sim 25 \mathrm{X}$ higher in the sludge. A possible reason for this is that when the concentration of $\mathrm{Pu} / \mathrm{Gd}$ is lower in the sludge, dissolution of Gd may be more impeded by the presence of the greater relative amount of the more soluble sludge components.

Table 4 presents the fractions of the respective elements soluble after the SRAT runs. Again the $\mathrm{Pu}$ ratios were determined using the corrected $\mathrm{Pu}$ activities and the assumption of $7 \mathrm{ml}$ of solution. The remaining fractions have been normalized so that the Sludge-3 $\mathrm{Ca}$ fraction is $100 \%$ soluble(by dividing by 1.23 ). These fractions were determined using the measured ppm concentrations, the weights of the sludge, nitric acid, and water added, as well as the $w t \%$ supernate and element $w t \%$ in dry sludge values from Fellinger 2002.

At a $\mathrm{pH}$ of 3.5 in the absence of sludge it appeared that essentially all of the Gd was soluble while $10 \%$ of the $\mathrm{Pu}$ was soluble or $90 \%$ of the $\mathrm{Pu}$ remained insoluble. In the tests with sludge present the fraction soluble decreased as the final $\mathrm{pH}$ increased except that for $\mathrm{Ca}, \mathrm{Mg}$, and $\mathrm{Mn}$ in Test Sludge-5. This may be experimental error in the analyses of these three elements in the supernate of Test Sludge- 5 since the fractions soluble are expected to decrease in the $\mathrm{pH}$ region 4.5 to 6 (Coleman, 1994).

Table 4. Fractions (Percent) of Pu, Gd, and Major Sludge Elements Soluble in the Final Supernates of the Simulated SRAT Tests

\begin{tabular}{|c|c|c|c|c|c|c|c|c|c|}
\hline $\begin{array}{c}\mathrm{Pu} / \mathrm{Gd} \\
\text { Test }\end{array}$ & $\begin{array}{c}\text { Final } \\
\mathrm{pH}\end{array}$ & $\mathrm{Pu}$ & $\mathrm{Gd}$ & $\mathrm{Fe}$ & $\mathrm{Ca}$ & $\mathrm{Al}$ & $\mathrm{Ni}$ & $\mathrm{Mg}$ & $\mathrm{Mn}$ \\
\hline Supernate & 3.5 & $10^{\mathrm{a}}$ & $97^{\mathrm{a}}$ & $23^{\mathrm{a}}$ & $\mathrm{a}$ & $\mathrm{a}$ & $\mathrm{a}$ & $\mathrm{a}$ & $\mathrm{a}$ \\
\hline Sludge-1 & 3.5 & 6.4 & 47 & 0.84 & $\mathrm{~b}$ & 24 & 70 & $\mathrm{~b}$ & $\mathrm{~b}$ \\
\hline Sludge-2 & 3.5 & 3.3 & 41 & 0.53 & $\mathrm{~b}$ & 18 & 70 & $\mathrm{~b}$ & $\mathrm{~b}$ \\
\hline Sludge-3 & 4.0 & 1.2 & 37 & 0.36 & 100 & 12 & 64 & 100 & 99 \\
\hline Sludge-4 & 4.5 & 0.74 & 22 & 0.11 & 77 & 2.9 & 43 & 77 & 76 \\
\hline Sludge-5 & 6.0 & 0.32 & 13 & 0.070 & 93 & 0.77 & 39 & 94 & 88 \\
\hline SRAT (c) & 3.8 & 0.06 & 2.64 & 0.32 & 94 & 9.30 & $59.0^{\mathrm{d}}$ & 105 & 97 \\
\hline
\end{tabular}

(a) There was no sludge in this test. (b) These were assumed 100\% soluble based on data in Table 3 and data in Table 24 of Fellinger, 2002. (c) Results of SRAT cycle with expected Pu/Gd concentrations (Fellinger, 2002).(d) Calculated with results in Fellinger, 2002 
The fractions of the respective sludge elements soluble for Test Sludge-3 and the SRAT test with the expected $\mathrm{Pu} / \mathrm{Gd}$ concentration were essentially equal. However, in Test Sludge-3 with the higher $\mathrm{Pu} / \mathrm{Gd}$ concentration in the sludge, $1 \%$ of the $\mathrm{Pu}$ was soluble compared to $0.06 \%$ in the SRAT test and $37 \%$ of the Gd was soluble compared to $2.6 \%$.

\section{Appearance of the Solids in Settled and Centrifuged Slurries}

The simulated sludge used in the tests was uniformly mixed throughout the heating cycle. Figure 1 shows the small SRAT apparatus during heating with all six reaction tubes. No difference in sludge appearance was noted at the different $\mathrm{pH}$ 's. Reaction tubes in the

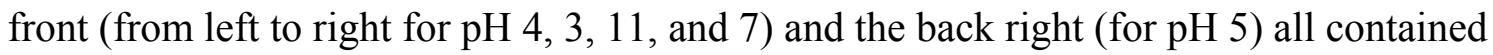
a mixed red brown material. Only the second wash supernate reaction was different. Since it only contained the small amount of $\mathrm{Pu} / \mathrm{Gd}$ solids it was a light green yellow color and was transparent enough to see the stirbar stirring (back row left vial).

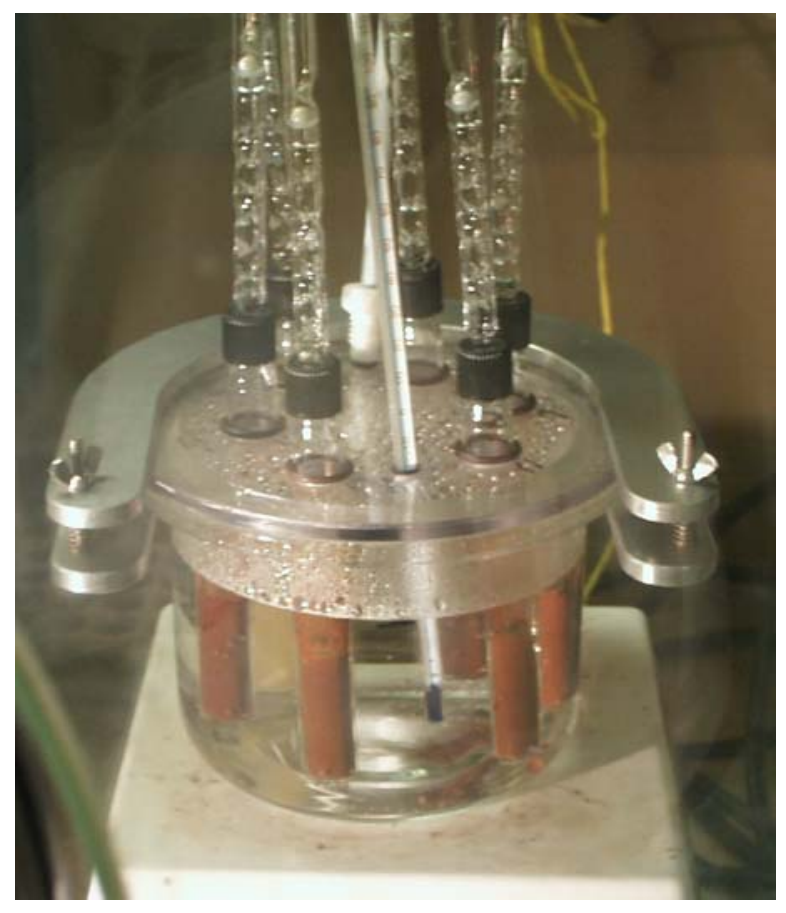

Figure 1. Sludge appearance while SRAT cycle was being run. 
Due to the small amount of material in each of the individual bounding tests, the slurried sludge used for obtaining a supernate sample was centrifuged rather than the usual gravity filtration method, which is used for larger samples. During the five minutes of centrifugation@ 3400 rpm, the samples experienced > 1000X the force of gravity (Fisher 2000/01). The solids separated into distinct zones. Solids from four reaction vials after the heating cycle, are shown in Figure 2 with their supernate removed. The far-left tube contains the $\mathrm{Pu} / \mathrm{Gd}$ solids from the second wash supernate reaction. The immediate conclusion that the heavier whitish green solids that separated in the sludge cases are the same as those in the second supernate reaction vial is incorrect.

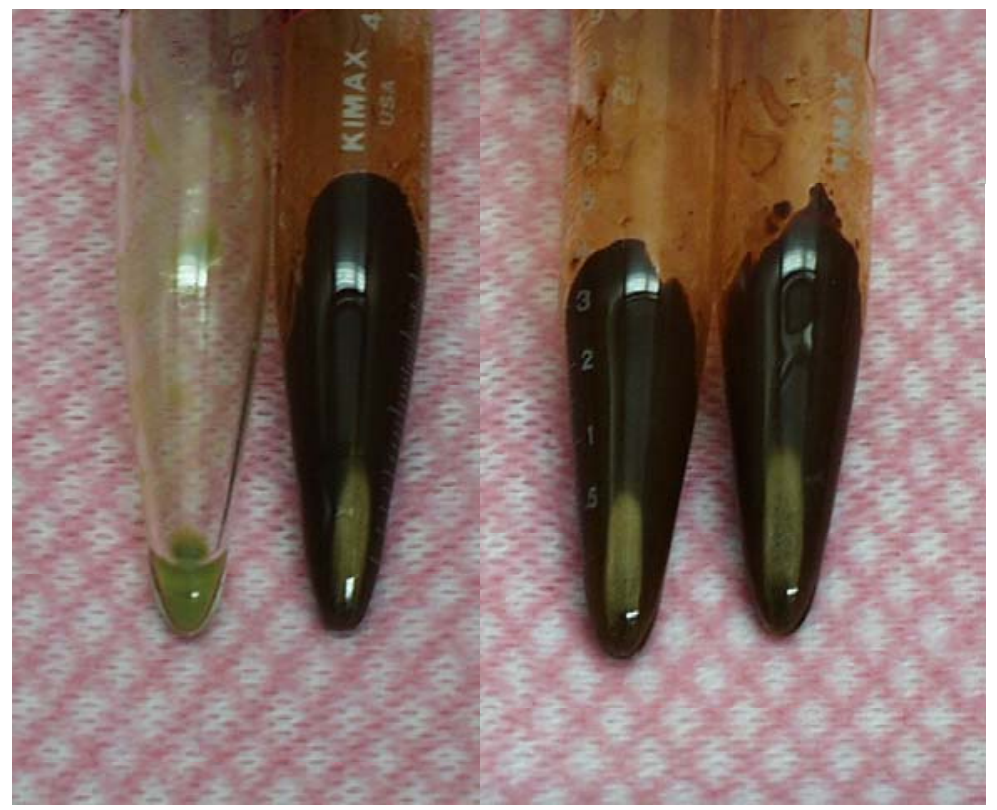

Figure 2. Centrifuged Pu/Gd and sludge solids after the simulated SRAT heating cycle. All samples with sludge had the same appearance (dark solids on top light solids on bottom).

SEM analyses were done on the top red brown material and the bottom whitish green solids. The whitish green solids were very fine and physically made up of more than one solid. SEM results only found Pu particles in one of the sludge samples of whitish green solids. As all of the other sludge samples looked the same but did not contain Pu solids, the white solids are mainly due to heavier particles of compounds of elements that were found such as zirconium $(\mathrm{Zr})$, barium $(\mathrm{Ba})$, chromium $(\mathrm{Cr}), \mathrm{Fe}$, etc. The darker solids 
were made up mainly of $\mathrm{Fe}, \mathrm{Ni}, \mathrm{Mn}, \mathrm{Ca}, \mathrm{Al}$, and silicon (Si). The SEM results will be discussed in the next section.

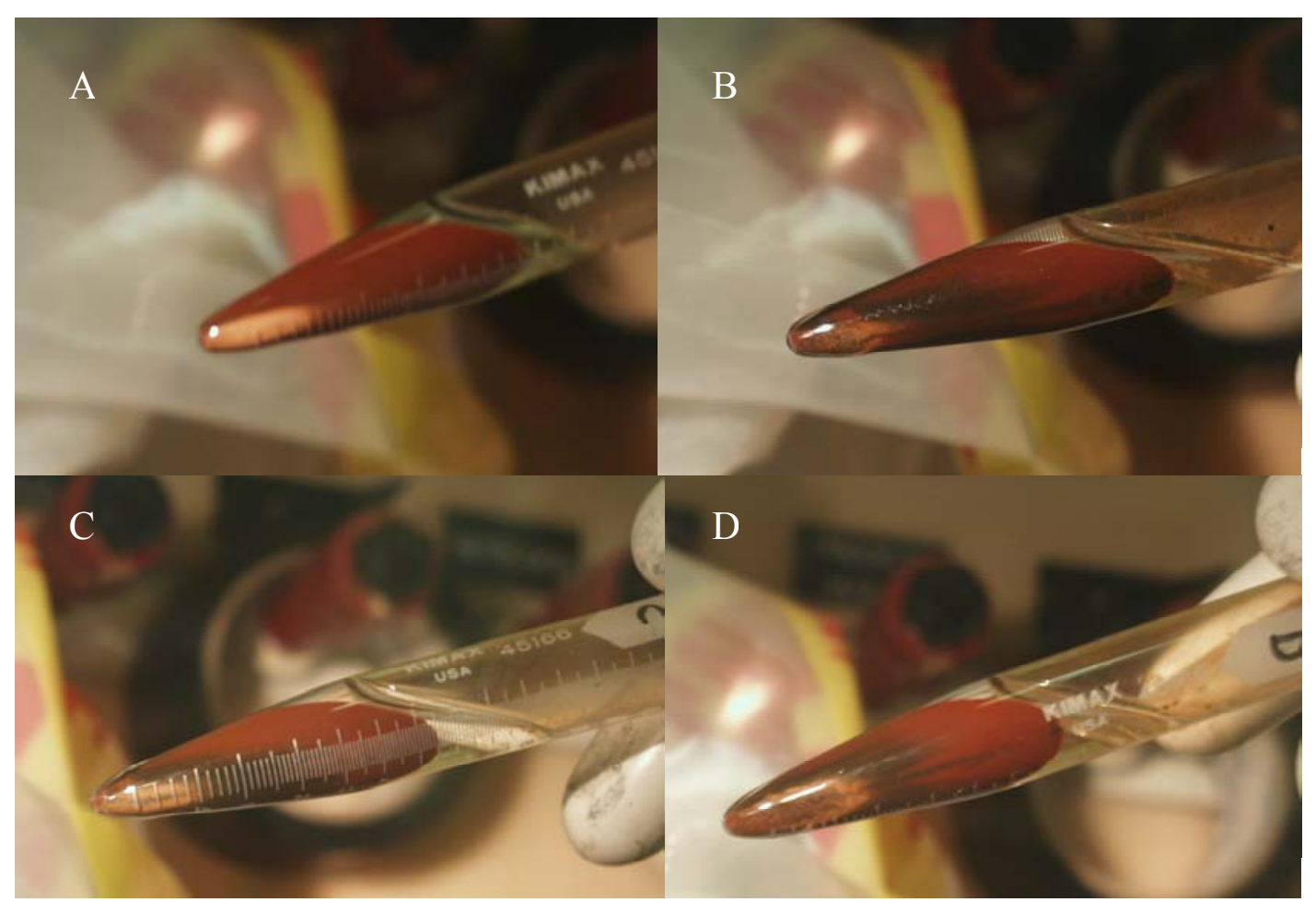

Figure 3. Centrifuged sludge solids; A) final simulated SRAT cycle product (Fellinger 2002), B) washed sludge sample with Pu Gd solids, C) de-washed simulated sludge prior to washing or Pu addition, D) washed sludge sample with $\mathrm{Pu} / \mathrm{Gd}$ solids. Note all sludge solids have lighter colored solids on the bottom (even $C$ the initial simulated sludge).

The separation of solids upon centrifuging the sludge brought up the question as to whether these solids were present in the sludge prior to the SRAT cycle run. To answer the question, four sludge samples were centrifuged for the same duration with the same centrifuge and compared. The resulting centrifuged sludges are shown in Figure 3. Sample A is the final SRAT cycle product.(Fellinger, 2002) Sample B is a washed sludge sample with $\mathrm{Pu} / \mathrm{Gd}$ solids added prior to spiking with extra $\mathrm{Pu} / \mathrm{Gd}$ for this testing. Sample C is dewashed simulated sludge prior to any washing (TK-8 RM-01073) or Pu addition. Here dewashed denotes washed simulated sludge which had the soluble waste components such as $\mathrm{NaOH}, \mathrm{NaNO}_{3}$, and $\mathrm{Na}_{2} \mathrm{CO}_{3}$ returned to it so it could be used as the simulated sludge used in the washing and SRAT work (Fellinger, 2002). Sample D is a washed sludge sample with $\mathrm{Pu} / \mathrm{Gd}$ solids added. Obviously, these whitish green solids 
are present in the sludge from the beginning to the end of the experiment. In fact, they are probably present in real sludge but due to their small size and the density of the sludge they do not preferentially separate.

The only major difference seen in the centrifuged solids is that sample A has a greenish blue supernate and no black solids. This is due to the Ni compounds becoming soluble which has been seen previously in SRAT cycles (Coleman, 1994, and Fellinger, 2002). A minor difference between the washed samples $B$ and $D$ and the initial dewashed simulated sludge is that the original simulated sludge appears to have more white solids. $\mathrm{B}$ and $\mathrm{D}$ solids are the same as expected since they were originally from the same solution.

The sludge appeared to settle homogeneously after one month. Figure 4 shows the small SRAT apparatus with all six reaction tubes after the sample removal followed by a

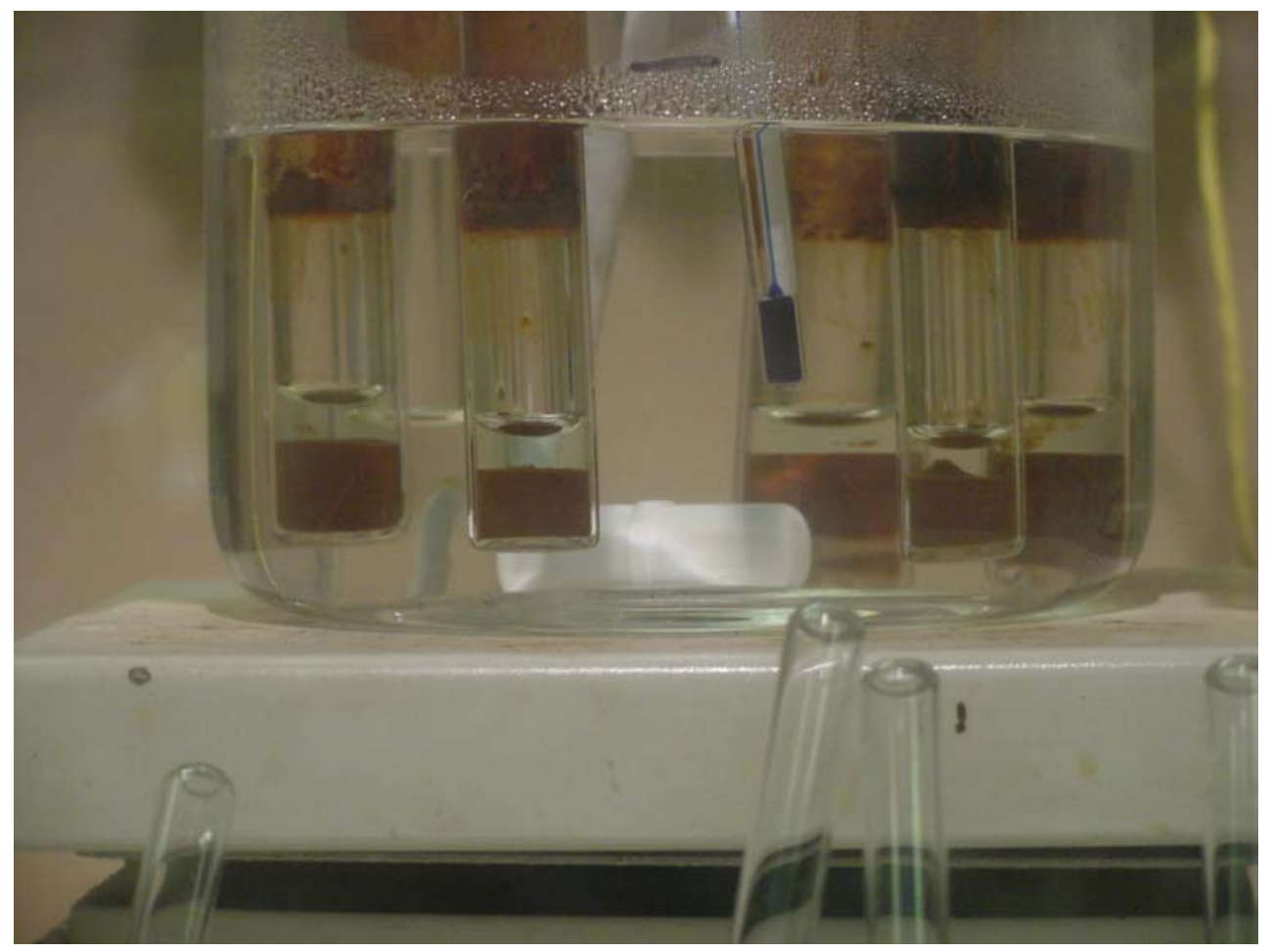

Figure 4. Sludge appearance after settling one month from the completion of the simulated SRAT run. No visible segregation of solid is seen. 
months settling. The reaction vials are in the same order as in Figure1. The supernate on all vials containing sludge solids is a light greenish blue. The sludge solids are of a uniform color and no white solids were seen on the bottom of the reaction vials. In the vial containing the second wash supernate, the Pu solids settled to a very thin layer on the bottom of the vial and on the stir bar. Upon lifting this vial the solids quickly dispersed to the solution making it cloudy. Lifting a tube with the sludge clouded the supernate also but did not remove the sludge layer.

\section{$\underline{\text { SEM Examination of the Centrifuged Solids }}$}

Samples of the centrifuged solids were obtained for SEM examination by breaking the centrifuge tubes and allowing the solids to dry. Samples of the dried solids were collected on adhesive tape on $1 \mathrm{~cm}$ diameter metal stubs for mounting in the SEM. For each test containing sludge, a sample of the brown solids on top and a sample of the lighter colored solids from the bottom (and thus heavier solids) were collected. A single sample of solids was collected from the test in absence of sludge (Supernate Test).

The SEM photomicrograph of the centrifuged solids in the Supernate Test (final $\mathrm{pH}=3.5$ ) with sludge absent closely resembled that of the $\mathrm{Pu} / \mathrm{Gd}$ solids as originally precipitated (see Appendix 6 of WSRC-TR-2002-00198), but the EDS spectrum was quite different. The EDS spectrum for the original solids showed both $\mathrm{Gd}$ and $\mathrm{Pu}$ in the solids (see Appendix 6 of WSRC-TR-2002-00198). The EDS spectrum of the solids from the Supernate Test (final $\mathrm{pH}=3.5$ ) is shown in Figure 5. No Gd was detected in these solids indicating that in the absence of sludge, the Pu and Gd that had originally been coprecipitated had separated. This behavior is presumably due to the higher solubility of $\mathrm{Gd}$ than $\mathrm{Pu}$ at low $\mathrm{pH}$ values. This separation phenomenon resulting from mixing and heating is similar to digestion of precipitates used in analytical chemistry. (Scoog, 1980) 


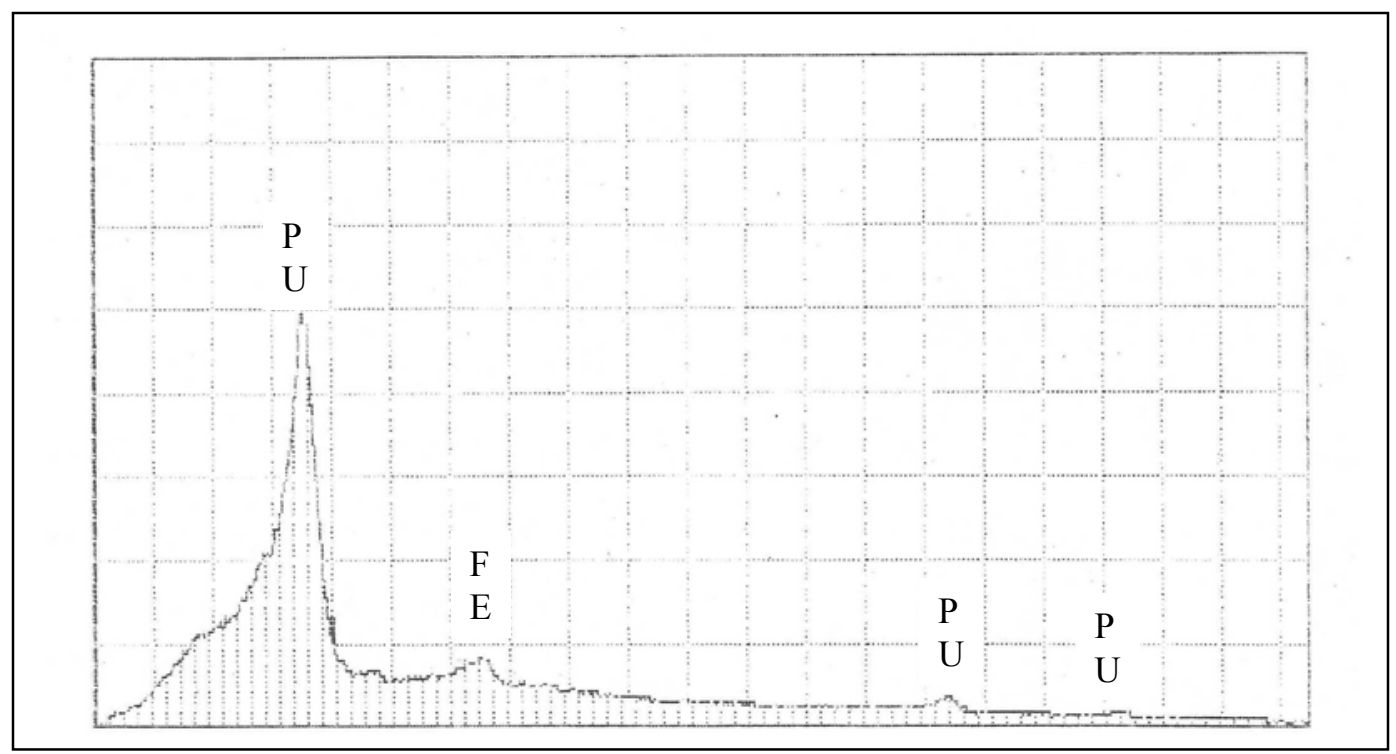

Figure 5. EDS Spectrum of particles from the Supernate Test (final $\mathrm{pH}=3.5$ ).

The SEM photomicrographs of the ten samples of centrifuged solids from the five tests with sludge present were all very similar except the SEM photomicrograph for the heavy solids in the Sludge-5 Test (final $\mathrm{pH}=6.0$ ) indicated that some $\mathrm{Pu}$ particles were present along with the sludge. The SEM photomicrograph for this sample is shown in Figure 6. EDS analysis of the bright particle in the center indicates that this particle was primarily $\mathrm{Pu}$. This result will be discussed later.

The dark background regions in the micrograph in Figure 6 are areas of the stub that had no particles on them. The lines are Ni wires imbedded in the adhesive on the stub to decrease the charging induced in the sample from the impinging electrons in the microscope beam. This prevents a charge from developing on the sample and affecting the quality of the SEM photomicrograph. Except for the Pu particles in Figure 6, all particles found were particles of sludge. These particles resembled the particles observed in all the other nine samples of centrifuged solids. Sludge particles are darker than the $\mathrm{Pu}$ particles because sludge has an overall lower atomic number than $\mathrm{Pu}$. In all the sludge particles examined in the ten samples, no Pu or Gd was detected by EDS analysis. Apparently the $\mathrm{Pu}$ and $\mathrm{Gd}$ were dispersed enough in the sludge so that they were not detected. 


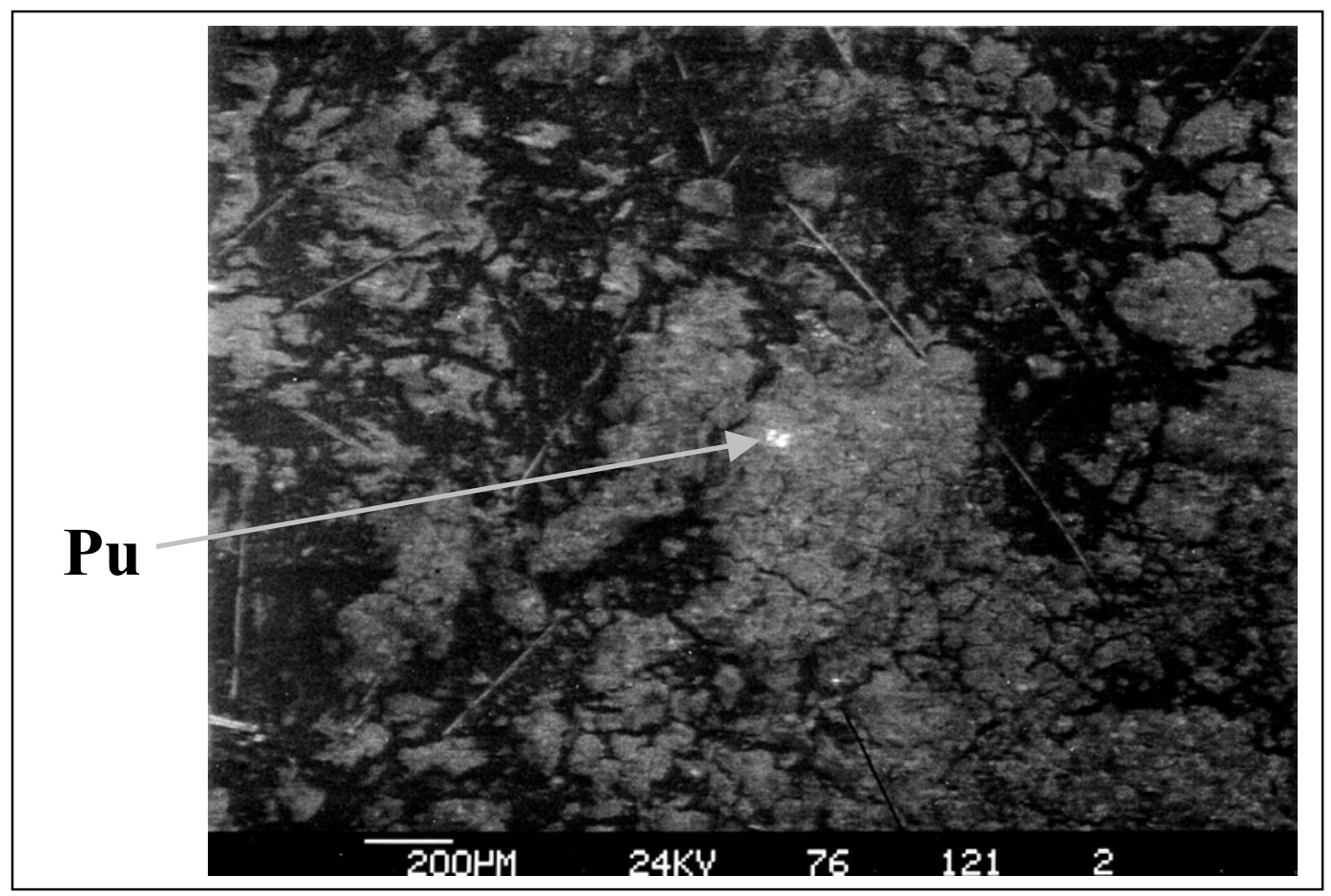

Figure 6. Scanning Electron Micrograph of sludge and Pu particles in centrifuged solids of Test Sludge-5 (final pH $=6.0 \pm 0.5$ ).

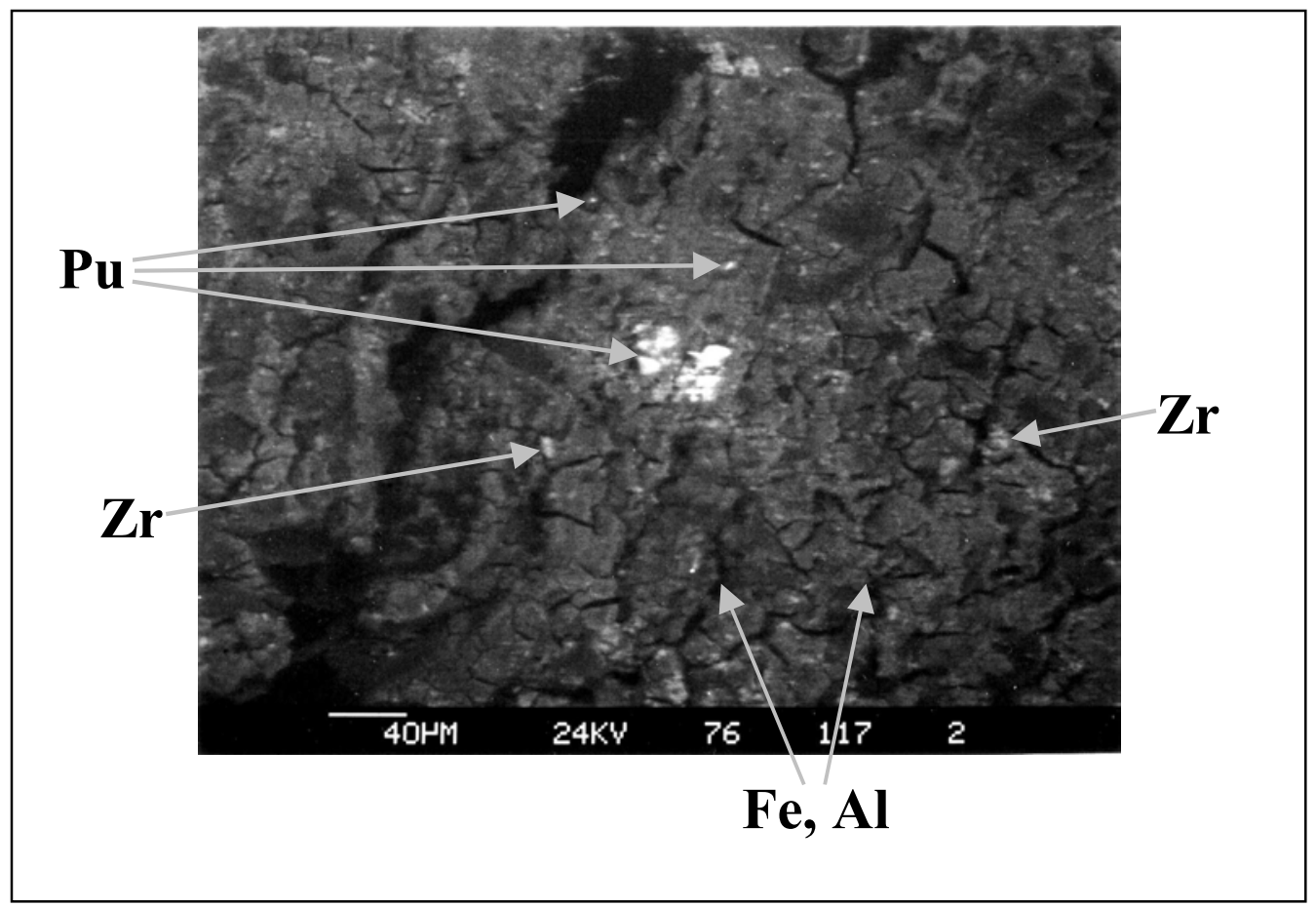

Figure 7. Scanning Electron Micrograph of sludge and Pu particles in centrifuged solids of Test Sludge-5 (final $\mathrm{pH}=6.0 \pm 0.5$ ) at a higher magnification. Particles that were analyzed by EDS are designated by the arrows. 


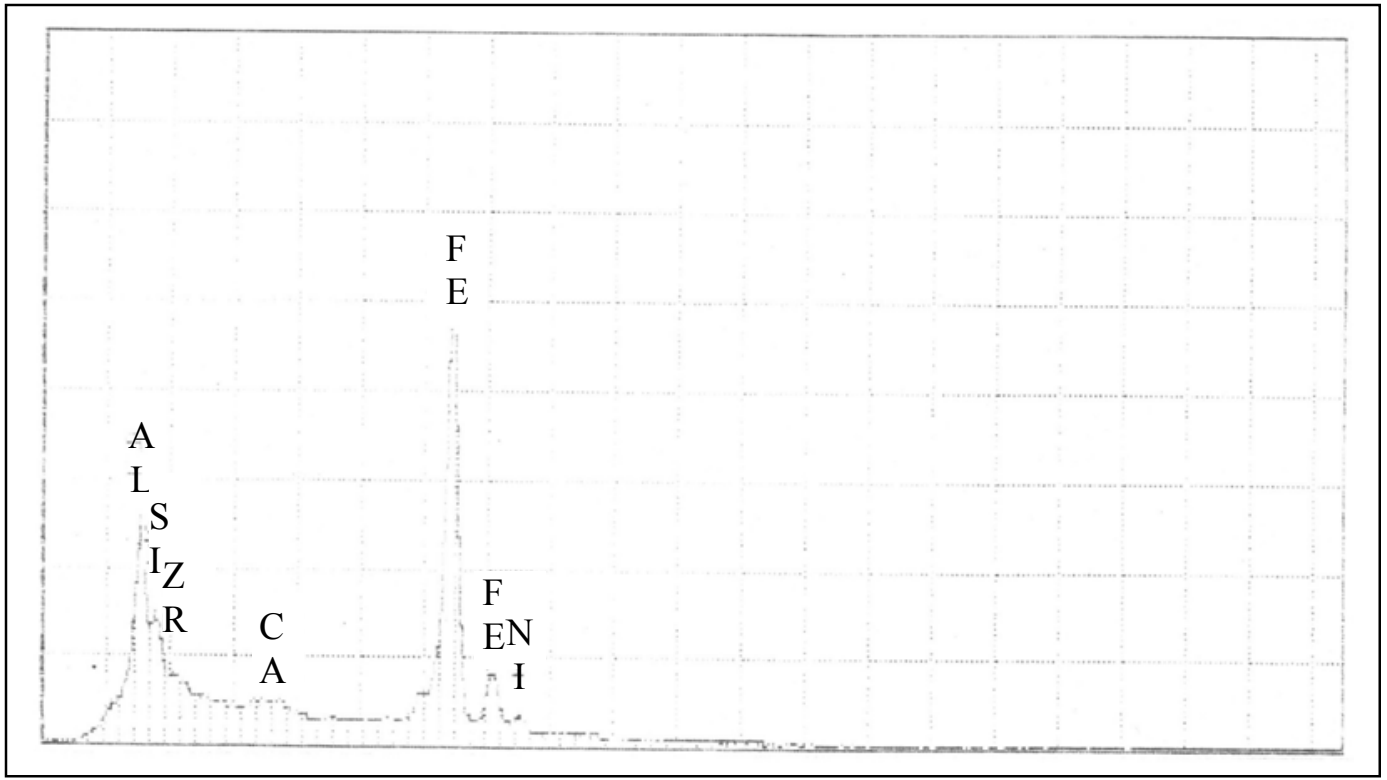

Figure 8. EDS spectrum of the sludge particles (Primarily Fe and Al) in centrifuged solids of Test Sludge-5 (final $\mathrm{pH}=6.0 \pm 0.5)$.

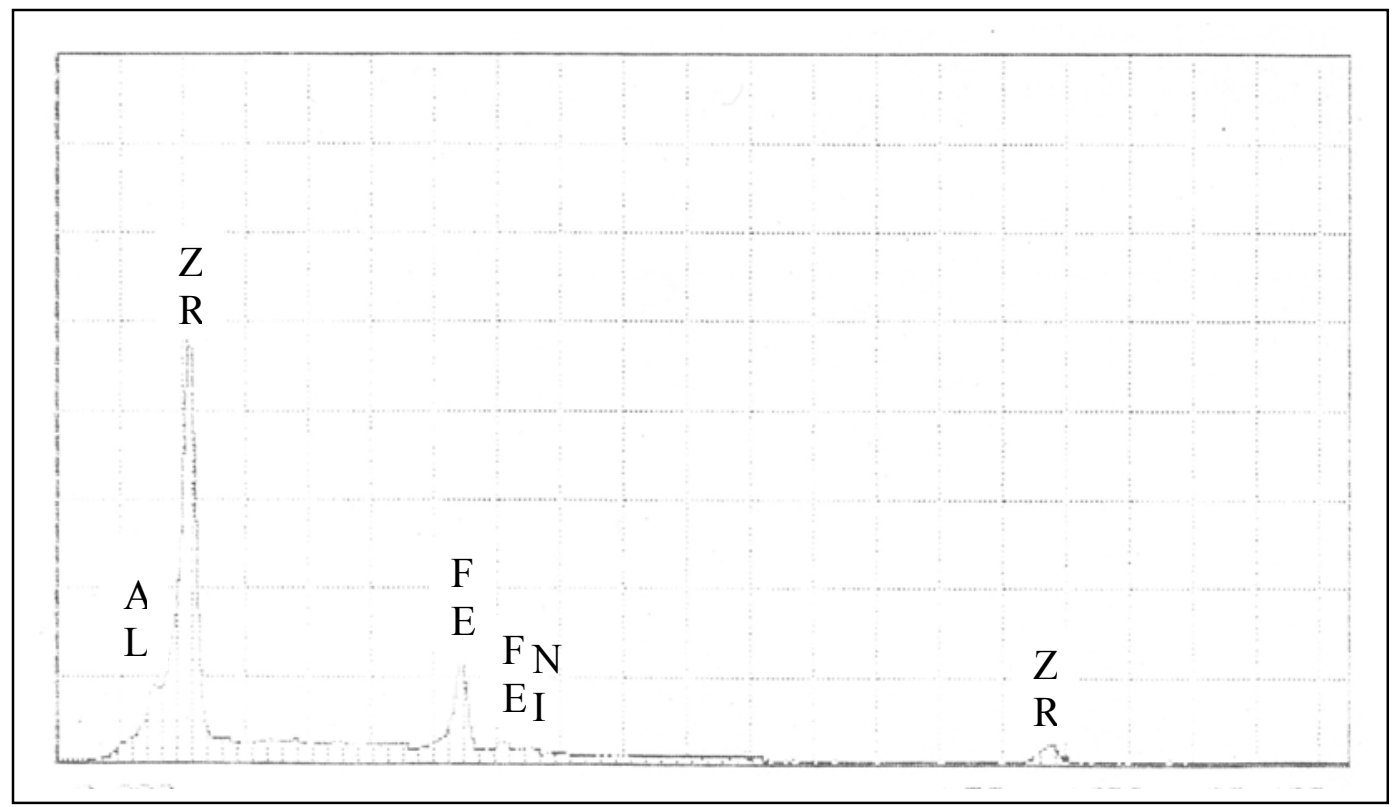

Figure 9. EDS spectrum of the $\mathrm{Zr}$ containing particles in centrifuged solids of Test Sludge-5 (final pH $=6.0 \pm 0.5$ ). 


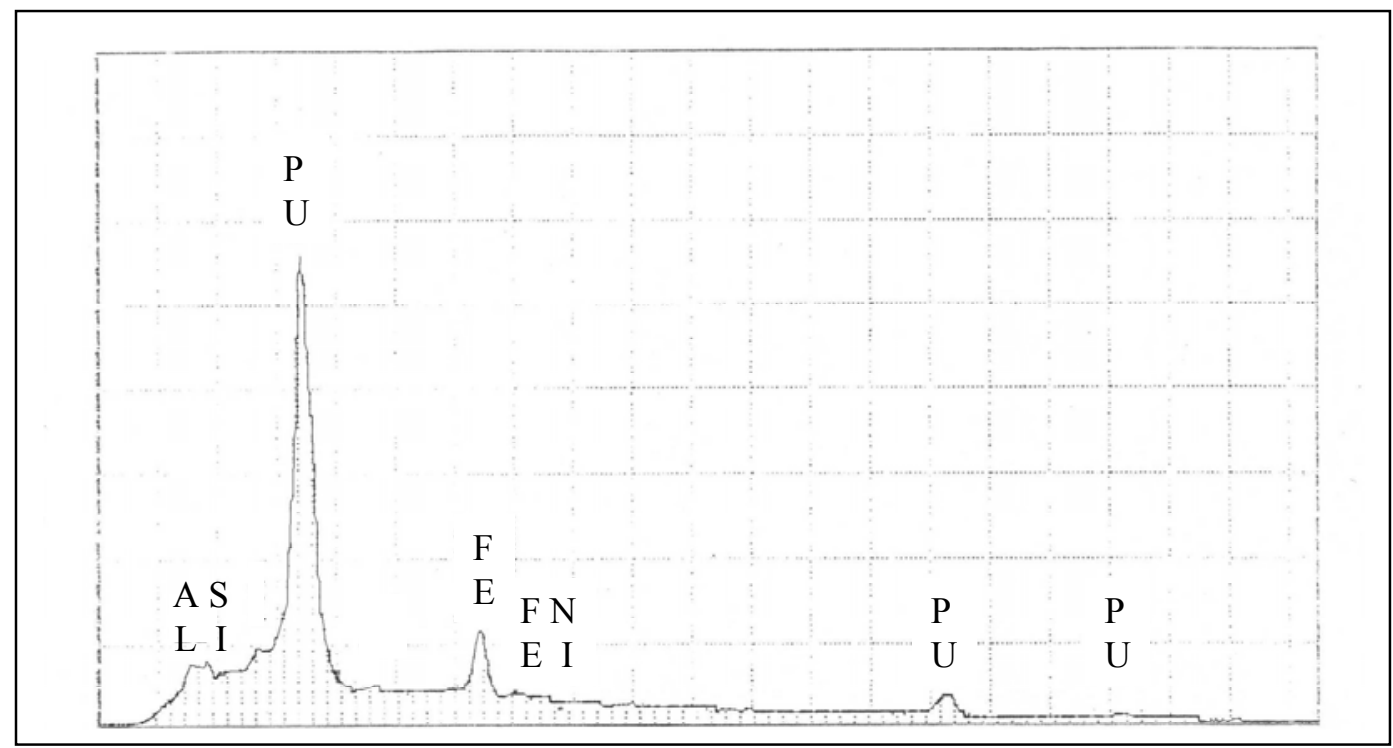

Figure 10. EDS spectrum of Pu particles found in the centrifuged solids of Sludge-5 Test (final $\mathrm{pH}=6.0 \pm 0 / 5$ ).

The Pu particles in Figure 6 will now be discussed. These particles were detected only after a detailed scan of all the solids on this $1 \mathrm{~cm}$ (10,000 microns) diameter stub. Figure 7 is a SEM micrograph of the same sample but at a $5 \mathrm{X}$ higher magnification. The arrows in Figure 7 point to particles that were analyzed by EDS. The major elements detected in the particles are labeled on the arrows. Figure 8 is an EDS spectrum of the sludge particles. This spectrum is typical of those obtained when the sludge was analyzed in all ten of the samples examined by SEM. Figure 9 is an EDS spectrum of some of the brighter sludge particles in Figure 7. This spectrum indicates that the particles are primarily Zr. These types of sludge particles were detected only in the bottom or heavier portions of the centrifuged solids. The top solids in the five tests with sludge were sludge particles that contained primarily the elements $\mathrm{Al}, \mathrm{Ca}, \mathrm{Mn}, \mathrm{Fe}$, and $\mathrm{Ni}$. The bottom centrifuged sludge solids in the five tests contained primarily $\mathrm{Al}, \mathrm{Ca}, \mathrm{Fe}$, and $\mathrm{Ni}$ along with the heavier elements $\mathrm{Zr}$ and $\mathrm{Ba}$. Centrifuging the samples caused this segregation. Figure 10 is the EDS spectrum of the Pu particles found in this sample. No Gd was detected, but the particles did contain some elements from the sludge. These were the only Pu particles detected on this sample. Finding discrete particles that contained Pu but no Gd indicates that a mechanism in the SRAT cycle exists that may lead to separation of 
some Pu and Gd. However, this separation cannot be spatially quantified with SEM since the particle size and iron concentration of the sludge can cause the Pu concentration to be at or below the limit of detection (LOD) of the technique.

\section{Conclusion}

A mechanism was found for separating Pu from Gd in the SRAT cycle. The separation could not be spatially quantified by SEM due to being at or below the LOD of the method. From solubility only $2.6 \%$ of the Gd is solubilized at normal SRAT conditions. $\mathrm{Pu}$ solubility, as expected, is very low, ranging from $0.32 \%$ to $10 \%$ in the bounding conditions studied. The Gd solubility appears to be dependent on the relative amount of the more soluble sludge components. In the $\mathrm{pH}$ and concentration range studied here, the amount of $\mathrm{Gd}$ that is solubilized ranges from $13 \%$ to $47 \%$ with sludge and essentially $100 \%$ in the absence of sludge. 
Immobilization Technology Section

WSRC-TR-2002-00211

Savannah River Technology Center

Rev. 0

Westinghouse Savannah River Company

Page 25 of 26

\section{References}

Fellinger, T. L., 2002, "Demonstration of the Tank Farm Washing Process and the DWPF SRAT Cycle with Sludge Batch 3 Simulant and Precipitated Pu/Gd Mixture from H-Canyon Tank 18.3," WSRC-TR2002-0020.

Coleman, C.J., Bibler, N.E., Ferrara, D.M., and Siegwald, S.F., "Reaction of Formic and Nitric Acids with Savannah River Site Radioactive HLW Sludge in the DWPF Pretreatment Steps (U)", Nuclear and Hazardous Waste Management-Spectrum 94, pp.737-741, Aug. 1994.

Bronikowski, M. G., et al., "Caustic Precipitation of Plutonium with Gadolinium for Disposition to High Level Waste," WSRC-TR-2002-00198.

Peeler, D. K., Bibler, N. E., and Edwards, T. B., 2002, “An Assessment of the Impacts of Adding Pu/Gd and $\mathrm{Am} / \mathrm{Cm}$ Waste Streams to Sludge Batch 3 (SB3) on DWPF H2 Generation Rates and Glass

Properties," WSRC-TR-2002-00145.

Skoog, D. A., and West, M. W., Analytical Chemistry $3^{\text {rd }}$ ed, pp.129-130, Holt, Rinehart, and Winston, Philadelphia, 1980.

Fisher Catalog 2000/2001 (p. 205) Centrifuge used is a Clay Adams Compact II Centrifuge single speed with timer. Typical single speed of Clay Adams centrifuges run at 3400rpm and 1049X gravity (SergeFuge model 2001) and 3300rpm @ 1580 x gravity (basic Dynamic II)

TK-8 RM-01073 sample RM is the drum label of the Tank 8 simulant used. 
Immobilization Technology Section

WSRC-TR-2002-00211

Savannah River Technology Center

Rev. 0

Westinghouse Savannah River Company

Page 26 of 26

This Page Intentionally Left Blank 